\title{
Pengaruh Penambahan Beeswax terhadap Kestabilan Fisik Lip Balm Berbasis Bioaktif Kakao
}

\author{
Ruqayyah, Sri Wahyuni, Khansa, Sartini \\ Fakultas Farmasi, Universitas Hasanuddin, Makassar, Indonesia
}

Kata Kunci :

Beeswax, Ekstrak Biji Kakao, Lemak Kakao, Lip Balm, Stabilitas Fisik

\section{ABSTRAK}

Biji kakao telah dimanfaatkan di Indonesia dalam proses produksi makanan, minuman dan produk farmasi. Dalam dunia farmasi biji kakao memiliki komponen bioaktif yakni, lemak kakao dan polifenol yang dapat dimanfaatkan dalam pembuatan lip balm. Lemak kakao memiliki kekurangan karena dapat membentuk kristal polimorf yang dapat diatasi dengan penambahan beeswax. Tujuan dari penelitian ini adalah mengetahui pengaruh penambahan beeswax pada berbagai konsentrasi terhadap kestabilan fisik lip balm yang akan diperoleh dengan menggunakan bioaktif kakao. Dalam penelitian ini uji kestabilan fisik yang dilakukan meliputi uji organoleptis, uji homogenitas, uji daya oles dan uji titik lebur. Hasil penelitian memperlihatkan bahwa warna, bentuk sediaan, uji homogenitas dan uji daya oles pada semua formula yang dibuat sama. Sedangkan uji titik lebur diperoleh hasil yang berbeda-beda yakni pada $\mathrm{F} 0$ $45^{\circ} \mathrm{C}, \mathrm{F} 150^{\circ} \mathrm{C}, \mathrm{F} 252^{\circ} \mathrm{C}$, dan $\mathrm{F} 355^{\circ} \mathrm{C}$.

\section{PENDAHULUAN}

Indonesia merupakan salah satu produsen kakao terbesar didunia. Kebanyakan biji kakao diekspor dalam bentuk biji kakao dan sebagian hasil hilirisasinya dalam bentuk produk makanan minuman. Biji kakao mengandung komponen bioaktif yang dapat dimanfaatkan dalam bidang farmasi antara lain: lemak kakao dan polifenol.

Lemak kakao merupakan komponen utama biji kakao. Hasil analisis kadar lemak kakao varietas lindak yang berasal dari Sulawesi Selatan berkisar sekitar 52 - 55 \% (1). Hasil penelitian Roiaini dkk, (2016) mendapatkan dalam lemak kakao yang diekstraksi menggunakan etanol 99,5 \% juga mengandung fitosterol. Lemak kakao dalam bidang farmasi digunakan sebagai bahan dasar sediaan suppositoria, dan berpotensi juga sebagai bahan kosmetika sediaan bibir, seperti lipstick dan lip balm (2).

Selain lemak kakao, bioaktif lainnya yang banyak dimanfaatkan adalah komponen polifenol kakao. Polifenol kakao dalam biji kakao bermanfaat sebagai antioksidan $(3,4)$.Kandungan dan jenis polifenol kakao tergantung dari varietas tanaman kakao (Theobroma cacao L.). Hasil penelitian sebelumnya menunjukkan kadar polifenol dalam ekstrak etanol biji kakao adalah 21,04 \% (5).

Lip balm atau balsam bibir merupakan suatu sediaan yang diaplikasikan pada bibir guna mencegah terjadinya pengeringan bibir dan melindunginya dari pengaruh lingkungan, seperti kelembaban udara yang rendah atau suhu yang terlalu dingin. Bahan utama lipstick maupun lip balm adalah carnauba wax, beeswax, carnauba wax, candelilla wax, paraffin and cocoa butter (lemak kakao), dan dapat ditambahkan bahan antioksidan, pewarna dan pengaroma (6).
Kekurangan lemak kakao adalah mempunyai Kristal polimorf, selain terdapat kristal yang stabil $(\beta)$ juga membentuk Kristal meta stabil $\left(\beta_{1}, \alpha, \gamma\right)$ yang meleleh pada suhukamar. Terbentuknya kristal ini dapat disebabkan karena pemanasan di atas $36^{\circ} \mathrm{C}$ atau adanya bahan yang dapat menurunkan titik lebur oleum kakao. Menurut Lachman (2008), hal ini dapat diatasi dengan penambahan beeswax konsentrasi $3-5 \%$ untuk digunakan dalam basis suppositoria (7).

Permasalahan dalam penelitian ini adalah konsetrasi berapakah beeswax yang digunakan dalam lip balm yang mengandung polifenol kakao dan lemak kakao yang menghasilkan kestabilan fisik yang memenuhi kriteria lip balm. Tujuan penelitian ini adalah mendapatkan formula lip balm ekstrak biji kakao yang memiliki kestabilan fisik yang baik.

\section{METODE PENELITIAN}

\section{Alat dan Bahan}

Alat-alat yang digunakan ayakan mesh 8 dan 14 . alat rotary evaporator (Buchi), penangas air, timbang analitik, shaker, sonikator VWR®, spektrofotometer UV-Vis, wadah kaca, wadah lip balm, Well Plate ELISA Reader.

Bahan-bahan yang digunakan dalam penelitian ini : beeswax, biji kakao, DPPH, etanol 70\%, fenoksietanol, pereaksi Follin ciocalteau, heksana, propilen glikol.

\section{Penyiapan Sampel Penelitian}

Biji kakao kering digiling dengan menggunakan blender hingga diperoleh serbuk dengan derajat halus 8/14. 


\section{Prosedur Kerja}

Ekstraksi Lemak Kakao dan Polifenol dari Biji Kakao

Sebanyak 200 g serbuk halus biji kakao diekstraksi dengan heksan dengan metode maserasi menggunakan bantuan alat sonikator dengan perbandingan sampel/pelarut 1:10 di sonikasi selama 30 menit dan didiamkan selama 24 jam. Kemudain dipisahkan hasil ekstraksi dan serbuk tidak larut heksan. Hasil ekstraksi dirotavapor pada suhu $50^{\circ} \mathrm{C}$ dengan kecepatan $80 \mathrm{rpm}$, hingga diperoleh lemak kakao

Rendamen ekstrak lemak kakao dihitung menggunakan rumus sebagai berikut:

Rendamen $=$ Berat lemak kakao $/$ Berat serbuk biji kakao $\times 100 \%$

Serbuk tidak larut heksana diekstraksi dengan etanol $70 \%$ (1:10) dengan metode maserasi dengan bantuan sonikasi selama 30 menit dan disimpan semalam. Setelah itu disaring dan diuapkan etanolnya dengan menggunakan rotavapour.

Penentuan Total Polifenol Ekstrak Biji Kakao

Ekstrak yang diperoleh ditentukan kadar total polifenol dengan metode spektrofotemetri UV-Vis menggunakan pereaksi Follin Ciocalteau dengan pembanding asam gallat (Kemenkes, 2011).

\section{Uji Aktivitas Antioksidan Ekstrak Biji Kakao dengan metode DPPH}

Ekstrak etanol yang diperoleh dibuat beberapa konsentrasi dan diuji aktivitas antioksidan secara in vitro menggunakan ELISA microplate reader dengan DPPH sebagai radikal bebas (Kemenkes, 2011).

\section{Pembuatan Lip Balm}

Lemak kakao dilebur di atas penangas air suhu $35^{\circ} \mathrm{C}$, selanjutnya ditambahkan bees wax

( 0 - $5 \%$ ), setelah melebur diturunkan dari penangas dan ditambahkan ekstrak kakao dan propil paraben yang sudah didispersikan dalam propilenglikol. Setelah itu dimasukkan ke dalam wadah lipbalm masing-masing $5 \mathrm{~g}$.

Evaluasi Kestabilan Fisik

Evaluasi yang dilakukan antara lain: pengamatan organoleptik yang meliputi warna, bentuk dan bau, homogenitas, uji daya oles, uji titik leleh.

\section{HASIL DAN PEMBAHASAN}

Hasil ekstraksi serbuk biji kakao untuk mendapatkan lemak kakao dengan metode maserasi perbandingan 1:10 dengan bantuan sonikasi selama 30 menit diperoleh hasil 18,554 g dengan persen rendemen sebesar 9,27 \%, Kisaran kadar lemak biji kakao Indonesia adalah antara 49\%-52\%, sedangkan hasil penelitian Langkong et al (8) diperoleh kadar lemak rata-rata dalam biji kakao dari 3 kabupaten di Sulawesi Selatan kurang lebih 52-54\%. Faktor-faktor yang menentukan rendemen lemak kakao yang diperoleh antara lain : perbandingan sampel dan pelarut, metode ekstraksi yang digunakan. Rendahnya rendemen yang diperoleh dengan metode maserasi kemungkinan karena lemak kakao belum terekstraksi semurna karena jumlah pelarut heksan yang digunakan cuma 10 bagian, sedangkan kandungan lemak kakao sekitar 52-54\%.

Untuk mendapatkan ekstrak yang mengandung polifenol kakao digunakan etanol sebagai cairan penyari etanol. Bagian tidak larut heksan dari hasil ekstraksi lemak kakao, selanjutnya diekstraksi dengan metode maserasi dengan bantuan sonikasi menggunakan etanol $70 \%$.

Pada penentuan kadar total polifenol diperoleh hasil dari metode maserasi sebesar 34,046\% lebih tinggi dari hasil penelitian Purwanngsih dkk (5) yang diekstraksi secara maserasi dengan kadar total polifenol rata-rata 21,04 \%. Ini kemungkinan karena adanya bantuan sonikasi getaran tinggi untuk memecahkan jaringan tanaman, sehingga senyawa polifenol lebih cepat terekstraksi.

\begin{tabular}{ccccc} 
Tabel 1. Rancangan Formula Lip Balm Kakao \\
\hline Bahan & \multicolumn{5}{c}{ Formula (\%) } \\
\cline { 2 - 5 } & F0 & F1 & F2 & F3 \\
\hline Ekstrak Kakao & 1 & 1 & 1 & 1 \\
Propilenglikol & 5 & 5 & 5 & 5 \\
Fenoksietanol & 0,5 & 0,5 & 0,5 & 0,5 \\
Bees wax & 0 & 1 & 3 & 5 \\
Lemak Kakao & 100 & 100 & 100 & 100 \\
\hline
\end{tabular}

Penentuan Aktivitas Antioksidan dilakukan secara in vitro dengan metode DPPH. Hasil uji aktivitas antioksidan dengan metode DPPH dari ekstrak etanol dari kedua metode, setelah dihitung $\mathrm{IC}_{50}$ diperoleh hasil untuk ekstrak yang diperoleh dari sampel yang diperoleh metode maserasi adalah 54,929 bpj. Hasil penelitian Imelda (10) diperoleh nilai IC50 ekstrak etanol terhadap DPPH dari beberapa klon biji kakao 6,4 bpj s/d 10,31 bpj.

Pada pembuatan lip balm, hasil uji kestabilan fisik dari ke empat formula menunjukkan hasil bau, warna, konsistensi, dan homogenitas yang hampir sama. Tujuan penambahan beeswax utamanya adalah untuk mencegah kemungkinan turunnya titik leleh oleum kakao yang kemungkinan disebabkan oleh penambahan senyawa fenolik seperti polifenol kakao dan pemanasan yang lebih dari $35^{\circ} \mathrm{C}$ (Lachman, 2008). Tetapi ada perbedaan titik leleh seperti terlihat pada Tabel 2.

\begin{tabular}{|c|c|c|c|c|}
\hline \multirow{2}{*}{ Evaluasi } & \multicolumn{4}{|c|}{ Formula } \\
\hline & Fo & F1 & $\mathrm{F} 2$ & F3 \\
\hline Bau & + & + & + & + \\
\hline Warna & + & + & + & + \\
\hline Konsistensi & + & + & + & + \\
\hline Homogenitas & + & + & + & + \\
\hline Daya oles & + & + & + & + \\
\hline Titik leleh & $45^{\circ} \mathrm{C}$ & $50^{\circ} \mathrm{C}$ & $52^{\circ} \mathrm{C}$ & $55^{\circ} \mathrm{C}$ \\
\hline \multicolumn{5}{|l|}{ Keterangan: } \\
\hline Bau & \multicolumn{4}{|c|}{ : (+) berbau cokelat } \\
\hline Warna & \multicolumn{4}{|c|}{ : (+) berwarna kecoklatan } \\
\hline Konsistensi & \multicolumn{4}{|c|}{ : (+) semi padat mendekati padat } \\
\hline Homogenitas & \multicolumn{4}{|c|}{$:(+)$ homogen } \\
\hline Daya oles & \multicolumn{4}{|c|}{$:(+)$ mudah dioles } \\
\hline
\end{tabular}

\section{KESIMPULAN}

Kestabilan organoleptik dari lip balm dengan penambahan $1,3,5 \%$ beeswax tidak terdapat perbedaan yang nyata, kecuali ada perbedaan dalam titik lebur lip balm.

\section{UCAPAN TERIMA KASIH}

Penulis mengucapkan terima kasih kepada kemenristek dikti Indonesia atas bantuan pendanaan. Penulis juga berterima kasih kepada Dekan Fakultas Farmasi atas penggunaan sarana dan prasarana di Laboratorium Fakultas Farmasi Universitas Hasanuddin.

\section{DAFTAR PUSTAKA}

1. Langkong, J., \&Laga, A. (2009). Mempelajari Perbandingan yang Tepat antara bubuk Kakao dengan Bubuk Kedelai Instan Sebagai Minuman Cokelat. Jurnal Sains danTeknologi Seri Ilmu-ilmuPertanian, 9(3)

2. Roiaini, M., Seyed, H. M., Jinap, S., \&Norhayati, H. (2016). Effect of extraction methods on yield, oxidative value, phytosterols and 
antioxidant content of cocoa butter.International Food Research Journal, 23(1), 47.

3. Diantika, F. (2015).Pengaruh Lama Ekstraksi Dan Konsentrasi Pelaru Etanol Terhadap Ekstraksi Antioksidan Biji Kakao (Theobroma Cacao L) (Doctoral dissertation, UniversitasBrawijaya).

4. Othman, A., Ismail, A., Ghani, N. A., \&Adenan, I. (2007).Antioxidant capacity and phenolic content of cocoa beans.Food chemistry, 100(4), 1523-1530.

5. Purwaningsih, D., AB, W. A., \& Megaputera, I.. Formulasi Sediaan Ekstrak Etanol Biji Kakao (Theobroma Cacao L.) Sebagai Kandidat Natural Antioxidant Melalui Teknologi Mikroenkapsulasi Dengan Metode Spraydrying. Program Kreativitas Mahasiswa-Penelitian.2013
6. Kadu, M., Vishwasrao, S., \& Singh, S. (2015). Review on natural lip balm. International Journal of Research in Cosmetic Science, 5(1), 1-7.

7. Lachman L., Herbert, A. L. \& Joseph, L. K., 2008, Teori dan PraktekIndustri Farmasi(terjemahan) ,Edisi III, 1119-1120, PenerbitUniversitas Indonesia, Jakarta.

8. Langkong, J., Ishak, E., Bilang, M., \& Muhidong, J. (2011). Pemetaan lemak dari biji kakao. Theobroma cacao.

9. DepKes, R. I. "Suplemen II Farmakope Herbal Indonesia." (2011): 66-67.

10. Emelda, A. "Polyphenol total content, IC50 and antioxidant activities of ethanol extract from some cocoa (Theobroma cacao) beans in South Sulawesi Indonesia." Journal of Chemical and Pharmaceutical Research 7.4 (2015): 1211-1214.

Sitasi artikel ini: Ruqayyah, Sri Wahyuni, Khansa, Sartini. Pengaruh penambahan Beeswax terhadap kestabilan fisik Lipbalm berbasis bioaktif kakao. MFF 2019; 23(2):61-63 